\title{
CULTURE AND ART
}

DOI https://doi.org/10.51647/kelm.2021.6.6

\section{KONSERWACJA ZABYTKOWEGO MALARSTWA ŚCIENNEGO ZABYTKÓW ARCHITEKTURY W KONTEKŚCIE DZIAŁAŃ KONSERWATORSKICH}

\author{
Viktoriia Zaitseva \\ aspirant Katedry Ekspertyzy Dziet Sztuki \\ Narodowej Akademii Kadr Kierowniczych Kultury i Sztuki, \\ starszy pracownik naukowy Narodowego Rezerwatu Przyrody „,Lawra Pieczerska” (Kijów, Ukraina) \\ ORCID ID: 0000-0002-1032-0601 \\ e-mail:v.zaitseva@dakkkim.edu.ua
}

\begin{abstract}
Adnotacja. W artykule rozważono cechy renowacji monumentalnego malarstwa Ławry Peczerskiej w Kijowie na przykładzie malowideł zachowanych po wybuchu malowideł soboru katedralnego Zaśnięcia Matki Bożej i zewnętrznego malarstwa ściennego nadbramnej cerkwi Świętej Trójcy, które do tej pory nie były przedmiotem specjalnych badań. Przedstawiono ogólną problematykę konserwacji malowideł ściennych, przeprowadzono analizę kompleksowych badań poprzedzających prace. Prześledzono ścieżkę ewolucji narodowej teorii i praktyki konserwatorskiej, koncentrujac się na rozważaniu różnych podejść naukowych i metod konserwacji historycznych malowideł ściennych, zastosowanych metod i konsekwencji ich stosowania. W obiegu naukowym wprowadzane sa mało zbadane materiały dotyczace renowacji zachowanych fragmentów monumentalnego malarstwa kaplicy Jana Ewangelisty soboru Zaśnięcia Matki Bożej oraz rekonstrukcji malowideł nadbramnej cerkwi Świętej Trójcy z okresu poprzedniego i nowożytnego.
\end{abstract}

Słowa kluczowe: malarstwo monumentalne, badania, renowacja, Ławra Pieczerska.

\section{PRESERVATION OF HISTORICAL MURAL PAINTING OF ARCHITECTURAL MONUMENTS IN THE CONTEXT OF RESTORATION MEASURES}

\author{
Viktoriia Zaitseva \\ Postgraduate Student at the Department of Art Study Expertise \\ of National Academy of Managerial Staff of Culture and Arts, \\ Senior Researcher of National Reserve "Kyiv-Pechersk Lavra"(Kyiv, Ukraine) \\ ORCID ID: 0000-0002-1032-0601 \\ e-mail:v.zaitseva@dakkkim.edu.ua
}

\begin{abstract}
The paper considers the peculiarities of the restoration of the monumental painting of the Kyiv-Pechersk Lavra on the example of paintings of the Assumption Cathedral, preserved after the explosion, and the mural of the exterior of the Trinity Gate Church, which have not been the subject of special study up to the present. The general problems of mural preservation are outlined, the analysis of the complex researches which preceded works is carried out. The way of evolution of the national restoration theory and practice is identified, emphasizing attention to consideration of various scientific approaches and methods of preservation of historical mural paintings, the applied techniques and consequences of their use. The underexamined materials on the restoration of the preserved fragments of the monumental painting of the surviving side chapel of St. John the Theologian in the Assumption Cathedral and the characteristics of the restoration of the Trinity Gate Church paintings of the previous and modern periods are introduced into scientific discourse.

Key words: Kyiv-Pechersk Lavra, Assumption Cathedral, reconstruction, research, murals, restoration.
\end{abstract}

\section{ЗБЕРЕЖЕННЯ ІСТОРИЧНОГО СТІНОПИСУ ПАМ'ЯТОК АРХІТЕКТУРИ В КОНТЕКСТІ ПРОВЕДЕННЯ РЕСТАВРАЦІЙНИХ ЗАХОДІВ}

\author{
Вікторія Зайцева \\ аспірантка кафедри мистецтвознавчої експертизи \\ Національної Академії керівних кадрів культури і мистецтв, \\ стариий науковий співробітник Національного заповідника \\ «Кисво-Печерська лавра» (Київ, Україна) \\ ORCID ID: 0000-0002-1032-0601 \\ e-mail:v.zaitseva@dakkkim.edu.ua
}


Анотація. У статті розглянуто особливості реставрації монументального живопису Києво-Печерської лаври на прикладі збережених після вибуху розписів Успенського собору та стінопису екстер'єру Троїцької надбрамної церкви, що до сьогодні не були предметом спеціального вивчення. Окреслено загальну проблематику збереження розписів, здійснено аналіз комплексних досліджень, що передували роботам. Простежено шлях еволюції національної реставраційної теорії і практики з акцентом на розгляді різних наукових підходів та методів збереження історичних стінописів, застосованих методиках та наслідках їх використання. До наукового обігу вводяться малодосліджені матеріали щодо реставрації збережених фрагментів монументального живопису вцілілого Іоано-Богословського приділу Успенського собору та характеристика відновлення розписів Троїцької надбрамної церкви попереднього та сучасного періодів.

Ключові слова: монументальний живопис, дослідження, реставрація, Києво-Печерська лавра.

Вступ. Ансамбль Києво-Печерської лаври - унікальний та найбільший музейний комплекс України, внесений до списку Всесвітньої спадщини ЮНЕСКО. Його архітектура всебічно відображає культуру, традиції, мистецьке та духовне життя українського народу певної історичної доби. Монументальний живопис Лаври, що органічно пов'язаний з архітектурною пластикою, представлений у зразках стінопису XII, XVII, XVIII та XX ст., за своїм обсягом та художнім значенням займає чільне місце у розмаїтті національної та світової мистецької спадщини. Проте, підвладний безжальному впливу часу, твір будь-якої мистецької якості втрачає свою первинну красу та цілісність. Рахунок цих втрат збільшують історичні події минулого, війни, пожежі та стихійні лиха, природне старіння матеріалів як складових кожної пам'ятки.

Основна частина. Збереження та реставрація пам'яток архітектурно-мистецької спадщини є однією 3 найактуальніших та наукоємних проблем сьогодення через нечисленність збережених об'єктів і значну втрату їх автентичності внаслідок колишніх ремонтів, перебудов, оновлень. Попри наявність фахових досліджень, тема збереження та реставрації їх художнього оздоблення висвітлена недостатньо та потребує поглибленого вивчення. Основним завданням роботи є зосередження уваги на дослідженні пам'яток монументального живопису як джерел інформації про розвиток культури та мистецтва, зумовлене необхідністю переосмислення, узагальнення та надання оцінки попереднього практичного досвіду їх реставрації. Мета дослідження - проаналізувати наукові методи та прийоми, застосовані під час відновлення монументальних розписів Троїцької надбрамної церкви та вцілілих фрагментів живопису Успенського собору Києво-Печерської лаври, в контексті подальшого їх збереження, пристосування та експлуатації. У роботі застосовано методи узагальнення та систематизації, історичний метод та порівняння з залученням спеціальних методів, якими користуються у проведенні комплексних обстежень пам'ятки: натурне дослідження, техніко-технологічний аналіз, спостереження. Дослідження побудоване на матеріалах з архівної проєктнореставраційної документації та висновків сучасного моніторингу об'єктів.

Одними 3 найдавніших будівель Києво-Печерської лаври є головна їі святиня - Успенський собор та Троїцька надбрамна церква, що увінчує центральні або «святі» ворота монастиря. Зазнавши за свою історію змін та перебудов, остаточні форми архітектура пам'яток набула в першій третині XVIII ст., отримавши

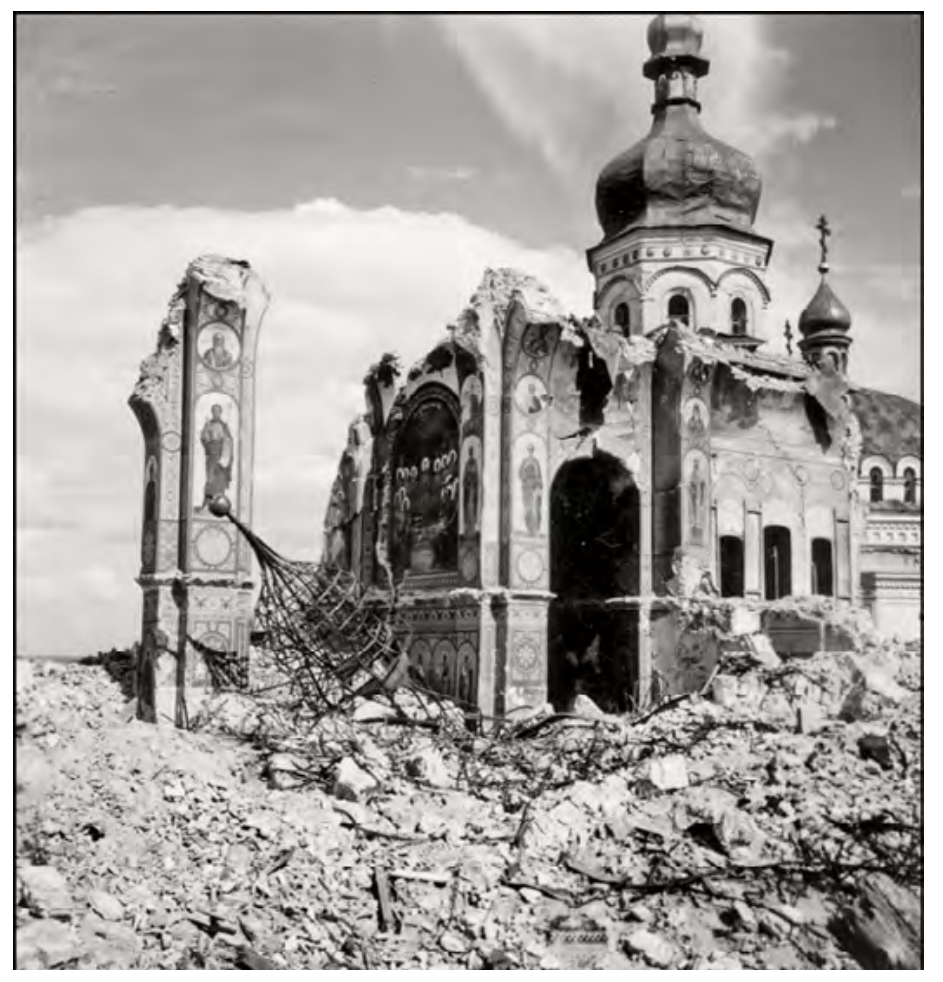

Рис. 1. Руїни Успенського собору після вибуху. 1943 р. Фото Г. Ліста 
весь репертуар декоративних прийомів, притаманних своєму часу: живописне оформлення площин, багатство пластики архітектурних деталей, підсилене світлотіньовою грою декоративного ліплення, а також використання елементів ордерної системи. Колористичне рішення фасадів слугувало тлом для барвистого живопису, яким були прикрашені екстер'єри храмів. Подальша доля цих пам'яток безпосередньо пов'язана 3 трагічними подіями Другої світової війни.

3 листопада 1941 р. Успенський собор був зруйнований вибухом, епіцентр якого знаходився між північною стіною давньоруської частини храму і внутрішньою Іоанно-Предтеченською церквою-хрещальнею. Наслідком події стало руйнування пілонів, склепінь та стін північної, західної частин собору та внутрішнього Іоанно-Предтеченського приділу (рис. 1).

Менше постраждала південно-східна частина собору та Іоанно-Богословський приділ з південною апсидою, верхнім вівтарем Св. Андрія Первозванного та вінцевою банею. Метод тимчасової консервації руїн Успенського собору, що полягав у розчищенні завалів, укріпленні контрфорсами решток мурувань та виявленні стародавнього розпланування храму, дав змогу на тривалий час забезпечити експозиційний стан пам'ятки (Прибєга, 2010: 149). Попри це, під купою сміття знаходилося безліч цінних меморіальних артефактів, які необхідно було вилучити (ЦДАВО України, Ф. 4762. Оп. 1. Спр. 451. Арк. 10). Крім того, Велика Успенська церква зберігала фрагменти останніх розписів та приховані залишки численних змін художнього оформлення інтер'єрів, чекаючи на нові дослідження. Знищення собору в 1941 р. спричинило фактичне знищення історії його живописного опорядження. Однак доповнити невідомі сторінки з історії художнього оздоблення унікальної пам'ятки допомогли виявлені під час археологічних розкопок матеріали. Зокрема, фрагменти штукатурки зі збереженими залишками розписів були знайдені під час проведення робіт з влаштування опалення собору в кінці XIX ст. Ці залишки були використані в якості забутовки кладки в 1893 р. Невеликі фрагменти від внутрішнього фрескового розпису знайдені в 1952 та 1962-1963 рр. під час розкопок престолу в центральній апсиді. Крім того, в 1962-1963 рр. особливу увагу привернув фрагмент фрескового розпису з зображенням орнаменту, що був виявлений між зовнішньою стіною стародавнього північного фасаду 1075-1077 pр. та південною стіною Стефанівського приділу, спорудженого в XV-XVI ст. (Xарламов, Коренюк, 1992: 81).

Як відомо, після вибуху від будівлі собору збереглися фрагменти східної стіни, частина південного нефа, нижня хрещальня, прибудова Іоанна Богослова та два стовпи XI ст., де збереглися фрагменти останніх монументальних розписів, виконаних в академічній манері в техніці олійного живопису в 1893-1896 рр. групою митців під керівництвом В. Верещагіна. До переліку першочергових невідкладних заходів в повоєнний період увійшли роботи з консервації вцілілих розписів. Надалі їхній стан збереження підтримувався за рахунок проведення незначних консерваційних заходів та влаштування захисного накриття.

Перша спроба розробити проєкт повної реконструкції Успенського собору була зроблена М. Холостенком. Можливість відтворення обгрунтовувалась наявністю вцілілих фрагментів, креслень, світлин та архівних матеріалів (Орленко, 2015: 171). Розробка проєктно-кошторисної документації на відновлення пам'ятки архітектури Успенський собор здійснювалась інститутом «Укрпроєктреставрація» на основі реставраційного завдання, затвердженого заступником голови виконкому міської ради народних депутатів Г.Н. Менжерес 9 грудня 1981 р. та ескізного проєкту реставрації, затвердженого Міністерством культури від 5 лютого 1986 р. Проєкту відновлення передували архітектурно-археологічні вишукування, аналіз та виявлення системи заходів, прийнятих під час будівництва стародавнього ядра, складання схем-картограм основних етапів формування пам'ятки, графічних реконструкцій собору різних періодів побутування. Ескізний проєкт відновлення Успенського собору розроблявся на основі достовірних науково-обгрунтованих даних та включав плани, фасади та розрізи.

Проте ідея відтворення зруйнованого Успенського собору формувалася на тлі гострих дискусій та суперечок. Зважаючи на оцінку проєкту реставрації, була виокремлена низка питань, що вимагали додаткового опрацювання. Так, незрозумілим було питання збереження та включення в нову будівлю залишків аутентичної кладки апсиди та інших збережених частин, серед них і вцілілих фрагментів живопису, 3 метою їх обов'язкового експонування.

В результаті технологічних досліджень 1986 р. з'ясовано, що стародавня кладка стін змішана 3 плінфи та каменю. Мурувальний розчин - вапняно-цем'янковий, у товщі стін дуже міцний, що має гарне зчеплення 3 плінфою та каменем. Місцями по кладці наявна обмазка рожевого кольору вапняно-цем'янкового складу. По обмазці фрагментарно зберігся шар пізньої вапняно-піщаної штукатурки товщиною до 10 см. Штукатурка мала відшарування від кладки. Стан збережених олійних розписів був аварійний: відшарування та лущення фарбового шару, багато втрат. Вся кладка, як стародавня, так і більш пізня (червона та жовта цегла на вапняно-піщаному розчині), пронизана сіткою тріщин: від волосяних до глибоких із розкриттям 1-2 см. Наразі аналіз стану пам'ятки показав, що реставраційні роботи повоєнного періоду з використанням цементних затирок порушили природній паро- та повітрообмін. Під затирками спостерігалося інтенсивне руйнування розчину, плінфи та цегли, відшарування цементу від основи. Також була завищена вологість стін, спостерігались локальні нальоти водорозчинних солей на південній стороні стін, де кладка схильна до замокань та більш інтенсивного висихання. 3 північної сторони - в затемнених місцях, на ділянках накопичення вологи - спостерігався розвиток зелених водоростей. Також були наявні декілька аварійних ділянок, що загрожували обвалом та потребували першочергових робіт з укріплення. 
На початку 90-х рр. ХХ ст. набула загальнодержавного значення проблема відтворення втрачених пам'яток відповідно до Указу Президента України Л. Кучми від 9 грудня 1995 р. «Про заходи щодо відтворення видатних пам'яток історії та культури». Видання зазначеного Указу активізувало призупинені роботи з реконструкції Успенського собору. Окрім унікальної мистецької значущості у становленні й розвиткові національної культури, доцільність реставраційної реконструкції Успенського собору визначалася, передусім, його важливою містобудівною роллю як композиційної домінанти лаврського ансамблю (Прибєга, 2010, с. 152). Запропонована реконструкція архітектури собору, відповідно до основних етапів будівельної еволюції, стала продовженням попередніх наукових досліджень, виконаних зокрема М. Холостенком, Г. Логвіним, Ю. Асєєвим, В. Харламовим, О. Пламеницькою та іншими вченими, і спробою їх узагальнення. Проте загальна концепція відбудови пам’ятки, порівняно 3 попереднім проєктом 1986 р., змінилася. Відновлення Успенського собору як засобу відродження цілісності архітектурного ансамблю Києво-Печерської лаври було підпорядковане відтворенню його функції - діючого храму, з можливістю експонування стародавніх частин собору (фундаментів, стін тощо) та проведення подальших археологічних досліджень. Таким чином до проєктних пропозицій було включено відтворення стінопису інтер'єрів Успенського собору, відновлення п'яти основних вівтарів 3 іконостасами, влаштування престолів, жертовників та «горніх місць», а також встановлення надгробків та священних рак.

Згідно з рішенням авторів проєкту, необхідно було провести заходи щодо розконсервації декоративнозахисної кладки та підлоги на майданчику Успенського собору та виконати консервацію стародавнього мурування. У виборі консерваційних заходів рекомендовано виконання мінімальної кількості доповнень для збереження автентичності мурувальних зондажів та можливості подальшого вивчення спеціалістами та забезпечення експонування. Водночас, «поглиблені історико-архівні, натурні дослідження, іконографічний матеріал та застосування фотограмметричного методу побудови втрачених архітектурно-конструктивних елементів пам'ятки надали право на достовірне відтворення собору з виявленням і подальшим відновленням естетичних та історичних цінностей пам'ятки в формах початку XVIII ст.» (Проєкт, 1998).

У 1998 р. фахівцями Державного науково-технологічного центру консервації та реставрації пам'яток (ДНТЦ «КОНРЕСТ») було здійснено обстеження стану залишків автентичного живопису, які планувалося включити до загальної програми відтвореного собору. Перебування фрагментів розписів у жорстких умовах під безпосереднім впливом зовнішнього середовища позначилося на їх стані. Картина виглядала жахливою: спостерігалися тріщини в цегляному муруванні, відшарування штукатурного шару від кладки, грунту від штукатурки, розтріскування, лущення та осипання фарбового шару. Становище ускладнювало те, що на пам'ятці велися роботи 3 конструктивного укріплення кладки стін, під час якого висвердлювались отвори, що призводили до додаткових втрат автентичного фарбового шару. Незалежно від загальної концепції розпису інтер'єрів собору спеціалістами було рекомендовано зберегти аутентичні фрагменти, використовуючи метод закріплення штукатурного та фарбового шару за методикою, яка традиційно застосовувалася

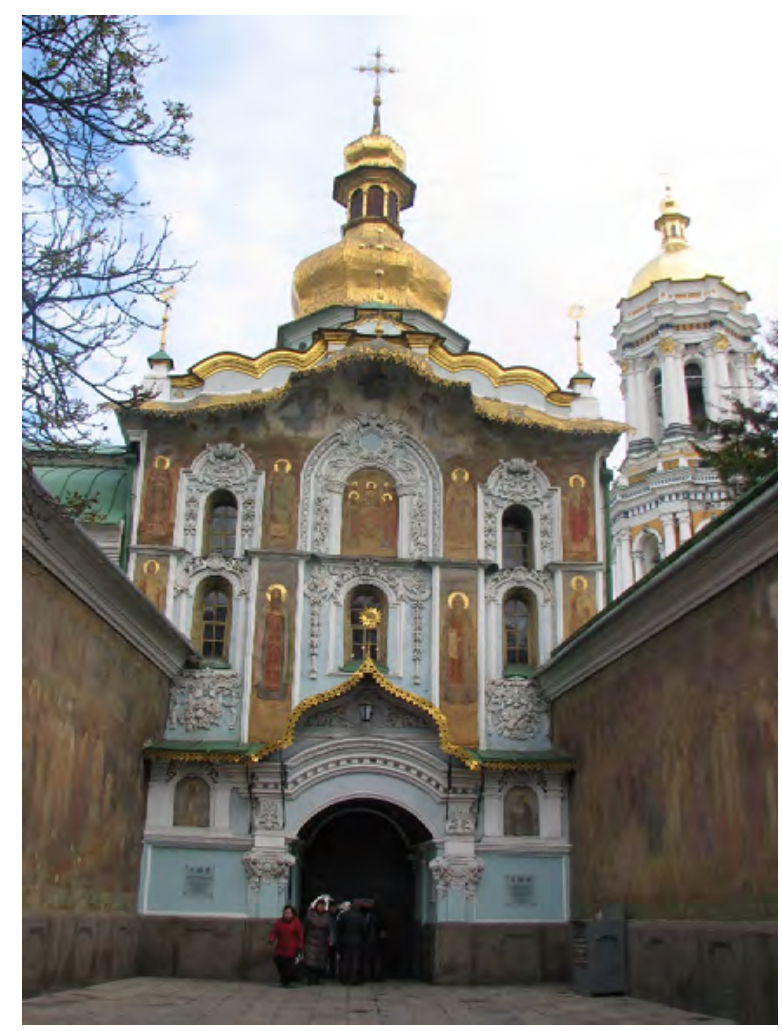

Рис. 2. Троӥцька надбрамна церква, західний фасад. 2018 р. 
в практиці реставрації монументальних олійних розписів - за допомогою воско-смоляної мастики. Однак ці роботи можна було виконувати тільки в теплий період року, що вчасно зроблено не було. Як було зазначено в «Рекомендаціях по заходах для збереження залишків живопису на руїнах Успенського собору...»: «При низьких температурах укріплення може не тільки не принести позитивних результатів, а й завдати икоди, призвести до додаткових втрат живопису, ускладнити його подальшу реставрацію» (Проєкт, 1998). Крім того, було висловлено застереження щодо вкрай обережного виконання будівельних робіт із конструктивного укріплення стародавнього мурування, аби уникнути втрати штукатурки з живописом. Для захисту поверхні фарбового шару від механічних пошкоджень та забруднення будівельними розчинами живопис закрили синтетичною сіткою з забезпеченням постійного контролю з боку реставраторів. Після реконструкції архітектурних елементів собору усі збережені фрагменти розписів були законсервовані.

Архітектурний проєкт Успенського собору втілений у життя у 2000 р. Подальша робота була пов’язана 3 науковим обгрунтуванням внутрішнього убранства храму. Чергове питання щодо збереження фрагментів аутентичного монументального живопису постало під час здійснення нового художнього оформлення інтер'єру Іоанно-Богословського приділу у 2013 р. Відновлення функції діючого храму вимагало відновлення всіх його атрибутів, зокрема й стінопису. Загальний стан та стильові особливості аутентичних розписів не вписувалися в загальну концепцію нового оздоблення. Для уникнення їх знищення деякі вцілілі фрагменти було вирішено закрити конструкцією з гіпсокартону, що стала основою для нового розпису в олійній техніці.

На відміну від Успенського собору, Троїцькій надбрамній церкві поталанило більше (рис. 2). Вона була єдиною на території Києво-Печерської лаври архітектурною пам'яткою, що збереглася після німецькофашистської окупації без значних руйнувань, однак потребувала термінових реставраційних заходів. В результаті незадовільного стану та порушення системи стоків наземних та підземних вод у безпосередній близькості від видатних архітектурних будівель виникло катастрофічне осідання грунту з утворенням великих провалів об’ємом до 500 куб. метрів (ЦДАВО України, Ф. 4762, Оп. 1. Спр. 456. Арк. 1). На західному фасаді Троїцької надбрамної церкви з'явилася тріщина, що спричинила втрати штукатурного шару та живопису. Зовнішній олійний розпис церкви безмірно потерпав від дії атмосферних чинників: перепадів температури, вологи, сонячних променів та забрудненого повітря промислового міста.

Характерною ознакою оформлення екстер'єру Троїцької надбрамної церкви було виконання розписів як на штукатурній основі, так і на металевих пластинах із вертикальним розміщенням на ділянках прясел та пілястр стін. Розписи були виконані в 1900-02 рр. київським художником В. Соніним (ЦДІАК України, Ф. 128. Оп. 2. Спр. 410). Після Другої світової війни було проведено декілька циклів реставраційних робіт на пам'ятці. Першочерговим завданням для українських хіміків-технологів та реставраторів був пошук та впровадження в реставраційну практику нових методичних розробок для консервації розписів, що знаходяться на відкритому повітрі. Повоєнна реставрація фасадів пам’ятки 1956-58 рр. базувалася на протиаварійних роботах та включала видалення зруйнованої штукатурки, відновлення втрачених деталей ліплення та заміну залізного покриття карнизів, виступів, навісів. Живопис на пілястрах та нішах фасадів, виконаних на цинкових листах, було запропоновано закріпити емульсією на основі натуральної оліфи, олійного лаку та воску (70\%-25\%-5\%). Штукатурний шар закріплювався за допомогою нагелей, місця втрат штукатурки доповнювалися новим вапняно-піщаним розчином, попередньо встановлюючи арматуру у вигляді сітки з металевого дроту (НЗКПЛ, КПЛ-А-1016: 22).

Враховуючи низьку ефективність органічних матеріалів та наголошуючи на більш ретельному науковому підході до вибору методик під час проведення чергових реставраційних робіт у 1976 р., для захисту розписів від впливу руйнівних факторів були використані найбільш стійкі покриття, рекомендовані українською науково-дослідною лабораторією. Для вирішення проблем закріплення штукатурної основи та в якості захисного покриття пропонуються нові методи фіксації з використанням синтетичних смол, головною властивістю яких була стійкість до атмосферних перепадів, біологічних чинників, морозостійкість та гідрофобність (Плющ, 1961: 11). В якості експерименту різні ділянки фасадів були вкриті різними захисними лаками - стійкими до перепадів температури та вологи, що мали антикорозійні властивості. Для живопису, виконаного на цинковій основі, була застосована методика, складена на основі архівних, техніко-технологічних досліджень та експериментальних консерваційно-реставраційних робіт, проведених безпосередньо на окремих ділянках живопису. Тонування втрат живопису було вирішено здійснити за допомогою сухих пігментів із додаванням смол, без детальної обробки живописних вставок.

Наразі питання збереження та реставрації зовнішніх настінних розписів Троїцької надбрамної церкви не втратило актуальності. Факт відсутності проведення своєчасної реставрації, «природне старіння» матеріалів, агресивне середовище, антропогенні та техногенні фактори призвели до виникнення негативних процесів у стані збереження монументального живопису та його основи. Зафіксовано локальні руйнування штукатурного шару та елементів оздоблення фасадів пам'ятки у вигляді втрат, відшарувань та розгалужених тріщин. Зв'язок фарбового шару та грунту з основою був порушений, наявні осередки втрат, лущень та жорстка деформація країв кракелюру. Внаслідок вигоряння пігментів авторського живопису та потемніння реставраційних тонувань та правок спостерігалось загальне спотворення колориту монументальних розписів. Водночас розписи на різній основі мали різний ступінь збереженості. Різкі перепади температури та вологості особливо згубно позначилися на стані живопису, виконаного на металевій основі. Тривала дія вологи та різке ії висихання викликало по всій поверхні зображень численні втрати. Процент вцілілого автентичного живопису на окремих зображеннях західного фасаду не перевищував 20-25\%. 
Таким чином, стан розписів церкви вимагав невідкладних заходів та поставив низку складних завдань перед сучасними художниками-реставраторами. Грунтуючись на висновках комплексних досліджень, фахівці склали оптимальну програму реставрації, що спирається на максимальне дотримання засад консервації, тобто мінімальне втручання в першооснову пам'ятки. За основу ідеї відновлення ансамблю розписів екстер'єру Троїцької надбрамної церкви був узятий принцип відновлення цілісності архітектурно-художнього образу пам'ятки, скерований науково обгрунтованими методами. 3 огляду на історико-архівні, бібліографічні вишукування, техніко-технологічні та натурні дослідження, було прийнято рішення відновити окремі зображення на металевій основі з реконструкцією втрачених елементів розпису. Наразі роботи тривають.

Висновки. Досвід досліджень, натурних обстежень та практика консерваційно-реставраційної роботи на лаврських об'єктах - зруйнованому Успенському соборі та Троїцькій надбрамній церкві - стали реальною школою реставрації для багатьох українських фахівців. Огляд бібліографічних джерел, опрацювання проєктної документації та аналіз дослідницької роботи надали можливість узагальнити попередній досвід практичної реставраційної роботи на пам'ятках із монументальним живописом та проаналізувати основні методи та прийоми як підгрунтя для оптимального вирішення сучасних нагальних проблем збереження. Головною метою стало відновлення цілісності всесвітньовідомих архітектурних пам'яток із максимальним збереженням автентичності пам'ятки, забезпеченням оптимальних умов збереження та експонування іiі оригінальних стародавніх частин.

\section{Список використаних джерел:}

1. Годовые отчеты о работе музея-заповедника «Киево-Печерская лавра» за 1950 год. ЦДАВО України (Центр. держ. архів вищих органів влади) Ф. 4762. Оп. 1. Спр. 451.

2. Документы (акты, докладные записки, постановления и др.) о ходе реставрации музея-заповедника «Киево-Печерская лавра» за 1950 год. ЦДАВО України (Центр. держ. архів вищих органів влади), Ф. 4762, Оп. 1. Спр. 456.

3. Научно-технический отчет по реставрации Троицкой надвратной церкви госзаповедника «Киево-Печерская лавра». 1962 г. НЗКПЛ (Нац. запов. «Києво-Печерська лавра»), КПЛ-А-1016.

4. Орленко М.I. Комплексні науково-реставраційні дослідження, науково-проєктні роботи 1981-1990рp. і програма наукових досліджень Успенського собору 1981 р. Сучасні проблеми архітектури та містобудування, Київ: 2015 (41), 166-175.

5. Плющ О.Ф. Рекомендации по методике закрепления пигментов древних фресок. Киев : Академия строительства и архитектуры УССР, 1961. 12 с.

6. Прибєга, Л. 3 історії охорони та реставрації пам'яток архітектури Києва. Українська академія мистецтв, Київ: 2010 (17), C. 143-153.

7. Рекомендації по заходах для збереження залишків живопису на руїнах Успенського собору. Проєкт відтворення Успенського собору Києво-Печерської лаври. НЗКПЛ (Нац. запов. «Києво-Печерська лавра», наук.-техн. архів), 1998. [рукопис].

8. Уведомление смотрителя лаврской иконописной школы иеромонаха Феогноста в Духовный собор КПЛ о приглашении иконописцев В. Сонина и Никиты Деревянки для росписи наружных стен Свято-Троицкой церкви. Подлинник. ЦДІАК України (Центр. держ. істор. архів), Ф. 128. Оп. 2. Спр. 410.

9. Харламов В.А. \& Коренюк Ю.А. Новые данные о технологии древних росписей Успенского собора Киево-Печерской лавры. Вопросы исследования и реставращии памятников архитектурыл, Київ : 1992. С. 80-88.

\section{References:}

1. Kharlamov, V.A. \& Koreniuk, Yu.A. (1992) Novye dannye o tekhnolohyy drevnykh rospysej Uspenskoho sobora KyevoPecherskoj lavry. [New data on the technology of ancient murals of the Assumption Cathedral of the Kiev Pechersk Lavra]. Voprosy yssledovanyia y restavratsyy pamiatnykov arkhytektury, 80-88. [in Russian].

2. Orlenko, M.I. (2015). Kompleksni naukovo-restavratsijni doslidzhennia, naukovo-proektni roboty $1981-1990$ rr. i prohrama naukovykh doslidzhen' Uspens'koho soboru $1981 \mathrm{r}$. [Complex scientific-restoration researches, scientific-design works 1981-1990 and program of scientific researches of the Dormition Cathedral 1981] Suchasni problemy arkhitektury ta mistobuduvannia, (41), 166-175 [in Ukrainian].

3. Prybieha, L. (2010) Z istorii okhorony ta restavratsii pam'iatok arkhitektury Kyieva. [From the history of protection and restoration of monuments of Kiev architecture]. Ukrains 'ka akademiia mystetstv, (17), 143-153. [in Ukrainian].

4. Rekomendatsii po zakhodakh dlia zberezhennia zalyshkiv zhyvopysu na ruinakh Uspens'koho soboru (1998). Proekt vidtvorennia Uspens'koho soboru Kyievo-Pechers'koi lavry [Recommendations for measures to preserve the remains of painting on the ruins of the Dormition Cathedral (1998)]. Reproduction project of the Assumption Cathedral of Kyiv-Pechersk Lavra (manuscript). [in Ukrainian].

5. The Central State Historical Archives of Ukraine (1899) Form 128; register 2 general, case 410. (manuscript) [in Russian].

6. The Central State Archives of Supreme Authorities and Governments of Ukraine (Central Executive Committee of Ukraine) (1950). Form 4762; register 1, case 456. [in Russian].

7. The Central State Archives of Supreme Authorities and Governments of Ukraine (Central Executive Committee of Ukraine) (1950). Form 4762; register 1, case 451. [in Russian].

8. The National Preserve "Kyiv-Pechersk Lavra" (1955). KPL-A-1016. [in Russian].

9. Pliusch O.F. (1961) Rekomendatsyy po metodyke zakreplenyia pyhmentov drevnykh fresok [Recommendations on the method of fixing the pigments of ancient frescoes]. Kiev: Akademyia stroytel'stva y arkhytektury USSR. 12 p. [in Russian]. 